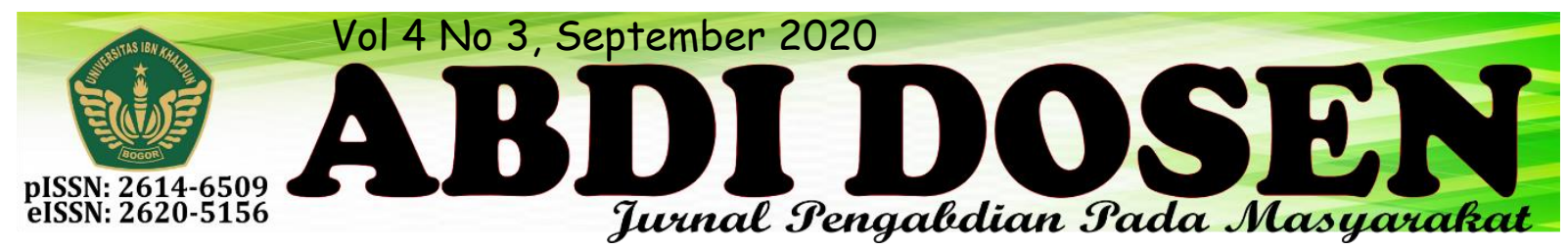

\title{
PENYEDIAAN FASILITAS BERUPA PENGOLAHAN LIMBAH RUMAH TANGGA DAN PENYEDIAAN SARANA AIR BERSIH MELALUI PERPIPAAN DI RT 02 RW 01 DESA PURASARI
}

\author{
Muhamad Lutfi ${ }^{1}$, Eny Dwimawati ${ }^{2}$, Iyan Ali Gunawan ${ }^{3}$ \\ mlutfi@ft.uika-bogor.ac.id ${ }^{1}$ \\ enydwisutomo@gmail.com ${ }^{2}$ \\ Dosen Fakultas Teknik dan Sains ${ }^{1}$, Dosen Fakultas Kesehatan ${ }^{2}$, Mahasiswa KKN Kelompok 21\&22 Tahun \\ $2019^{3}$
}

\begin{abstract}
ABSTRAK
Kegiatan pengabdian kepada masyarakat yang bertujuan untuk membantu masyarakat dalam memecahkan masalah, meningkatkan taraf pengetahuan, dan keterampilan, sehingga diharapkan dapat meningkatkan kesejahteraan masyarakat. Pelaksanaan kegiatan pengabdian kepada masyarakat ini dimulai dari bulan Agustus-September 2019 di Desa Purasari, Kecamatan Leuwiliang, Kabupaten Bogor. Sebelum menentukan program kerja, observasi dilakukan dengan metode studi kasus untuk mengamati secara langsung situasi, kondisi, sarana, dan prasarana yang ada di lokasi yaitu di Desa Purasari, ditemukan beberapa masalah di antaranya keterbatasan sumber air bersih, dan ketidaktahuan masyarakat dalam pemanfaatan limbah rumah tangga menjadi pupuk organik, serta masalah yang berhubungan dengan pendidikan, hukum, keagamaan dan ekonomi. Masalah ketersediaan air bersih dan limbah rumah tangga menjadi prioritas dalam kegiatan pengabdian pada masyarakat kali ini. Dalam mengatasi keterbatasan sumber mata air kami menggunakan metode Participatory Learning and Action (PLA) yang bekerja sama dengan masyarakat sekaligus memberikan edukasi dalam penyaluran sumber mata air bersih kepada warga desa sehingga dapat dimanfaatkan oleh masyarakat. Selain daripada itu kami menggunakan metode Anaerob untuk mengedukasi masyarakat dengan memberikan pelatihan pembuatan pupuk kompos organik cair yang dapat dimanfaatkan oleh masyarakat melalui pengolahan limbah rumah tangga sehingga dapat mengurangi jumlah limbah rumah tangga dan menjaga kebersihan lingkungan agar tetap bersih dan asri.
\end{abstract}

Kata kunci: limbah rumah tangga, lingkungan, sumber mata air.

\section{PENDAHULUAN}

Desa Purasari adalah salah satu desa yang berada di wilayah Kecamatan Leuwiliang Kabupaten Bogor, Provinsi Jawa Barat. Desa Purasari merupakan desa pemekaran dari desa induknya yaitu Desa
Puraseda sejak tahun 1970. Desa Purasari memiliki luas total wilayah 632,120 Ha. Desa Purasari memiliki lima wilayah kerja dusun, yang terdiri dari dua belas RW dan lima puluh RT. 


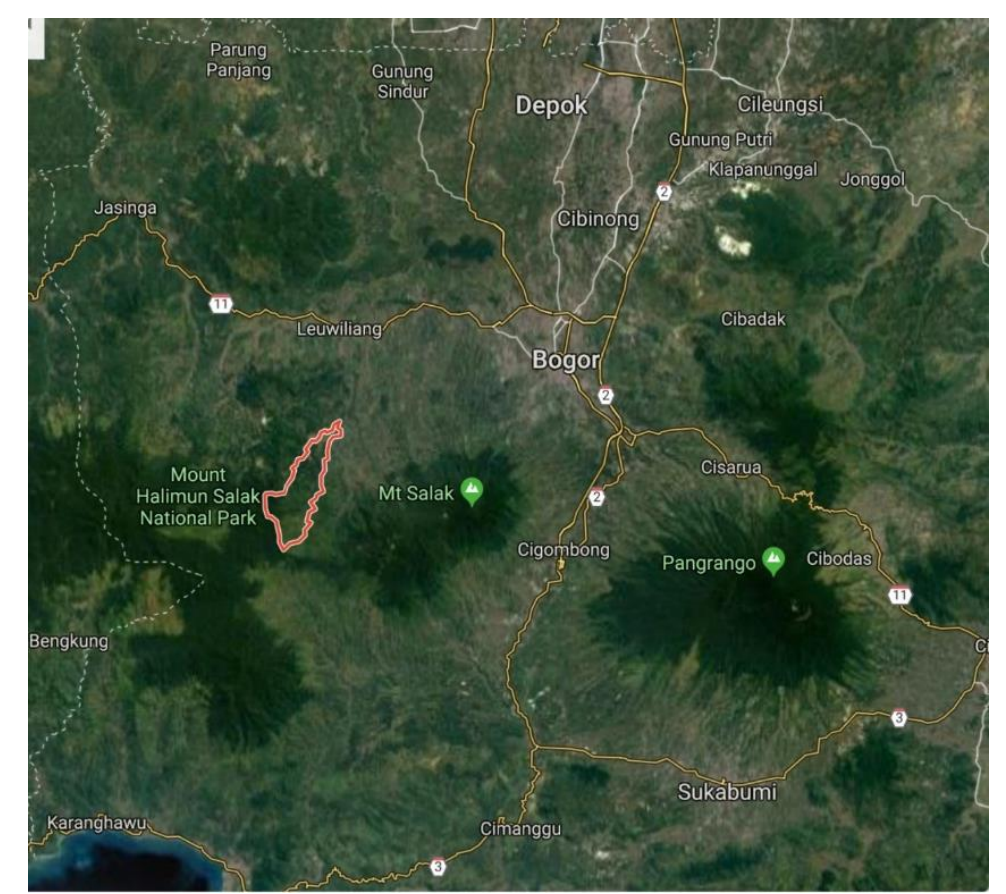

Gambar 1 Lokasi Desa Purasari Kecamatan Leuwiliang Kabupaten Bogor

Dilihat dari segi topografi Desa Pursari memiliki dua musim yakni enam bulan hujan dengan curah hujan $1200 \mathrm{Mm}$ dan enam bulan kemarau. Berdasarkan aspek hidrologi wilayah desa memerlukan pengendalian dan pengaturan dalam penataan air di wilayah desa. Sebagian masyarakat Desa Purasari memanfaatkan sumber mata air bersih sebagai sumber air utama bagi kebutuhan hidup sehari-hari maupun kebutuhan untuk mengairi pertanian yang berada di wilayah Desa Purasari. Beberapa mata air yang dipergunakan masyarakat adalah sebagai berikut:

Tabel 1 Sumber Mata Air Bersih

\begin{tabular}{|l|l|}
\hline No. & \multicolumn{1}{|c|}{ Nama Sumber Mata Air } \\
\hline 1 & Mata air Babakan Empang \\
\hline 2 & $\begin{array}{l}\text { Mata air Cikaret babakan } \\
\text { Asem }\end{array}$ \\
\hline 3 & Mata air Cikaret Pojok \\
\hline 4 & Mata air Babakan Panjang \\
\hline 5 & Mata air Cisarua \\
\hline 6 & $\begin{array}{l}\text { Mata air Tanjungsari/ } \\
\text { Tanjungsari Pojok }\end{array}$ \\
\hline
\end{tabular}

\begin{tabular}{|l|l|}
\hline 7 & $\begin{array}{l}\text { Mata air Tanjungsari/ } \\
\text { Cibagoak }\end{array}$ \\
\hline 8 & Mata air Cianten Pel \\
\hline
\end{tabular}

Penduduk Desa Purasari dengan jumlah penduduk 12.260 jiwa sampai dengan bulan Desember 2018, dengan jumlah Kepala Keluarga (KK) sebanyak 3.132 KK. Pertumbuhan penduduk di Desa Purasari rata-rata 215 orang/tahun. Peningkatan dan penurunan Laju Pertumbuhan Ekonomi (LPE) masyarakat berpengaruh secara tidak langsung ke dalam peningkatan kesejahteraan masyarakat. Adapun mata pencaharian masyarakat dapat dilihat pada tabel berikut:

Tabel 2 Jenis Pekerjaan

\begin{tabular}{|l|l|l|}
\hline No. & \multicolumn{1}{|c|}{ Jenis } & \multicolumn{1}{c|}{ Jumlah } \\
\hline 1 & Petani & 1726 Orang \\
\hline 2 & Pengrajin & 25 Orang \\
\hline 3 & Transportasi & 35 Orang \\
\hline 4 & Pedagang & 461 Orang \\
\hline 5 & PNS/TNI/POLRI & 27 Orang \\
\hline 6 & Lain - Lainnya & 9531 Orang \\
\hline
\end{tabular}


Berdasarkan Tabel 2 di atas, jumlah pekerjaan yang terbesar adalah petani, lapangan kerja petani mendominasi karena banyaknya lahan pertanian di daerah Desa Purasari.

Permasalahan di Desa Purasari adalah kurangnya persediaan air yang terjadi ketika curah hujan rendah, sehingga memengaruhi sumber mata air yang menjadi sumber kehidupan bagi masyarakat. Masyarakat Desa Purasari kerap kali mengambil air di fasilitas umum yang tersedia. Dengan permasalahan tersebut, kami anggota KKN 21 dan 22 yang ditempatkan di Desa Purasari berinisiatif untuk melakukan wawancara dengan ketua RW 01 dan membuahkan suatu hasil, di lingkungan RT 02 RW 01 terdapat suatu sumber mata air yang belum dapat dialirkan ke lingkungan warga karena keterbatasan pengetahuan dan biaya. Maka dari itu kami berinisiatif menjalankan program penyaluran air bersih bagi warga Desa Purasari khususnya lingkungan RT 02 RW 01.

\section{METODOLOGI}

Pengabdian dilaksanakan di Desa purasari, Kecamatan Leuwiliang, Kabupaten Bogor yang berjarak \pm 32 Kilometer atau sekitar 3 jam perjalanan darat dari Universitas Ibn Khaldun Bogor. Kegiatan KKN yang dilakukan oleh kelompok mahasiswa merupakan salah satu upaya untuk menerapkan hasil pembelajaran di perguruan tinggi kepada masyarakat, karena sebelum mahasiswa menerapkan ilmunya ke ruang lingkup masyarakat perlu dilakukan. Penelitian untuk menemukan permasalahan yang sedang terjadi selama KKN dan penemuan solusi baik jangka panjang maupun jangka
Mayoritas petani di Desa Purasari adalah mengelola sawah dengan menggunakan pupuk kimia atau anorganik untuk meningkatkan hasil panen. Permasalahan yang terjadi di kalangan para petani adalah meningkatnya biaya produksi karena kondisi tanaman dan luas daerah yang ditanam dapat meningkat dan membutuhkan penggunaan pupuk kimia yang lebih banyak. Wawancara yang dilakukan dengan kepala Desa Purasari mengatakan bahwa mereka sudah pernah mendapatkan pelatihan pembuatan kompos akan tetapi pada saat pelatihan dilakukan terjadi kekeliruan target peserta, peserta yang datang tidak diprioritaskan untuk para petani yang memiliki sawah maupun usaha tani akan tetapi pelatihan tani diberikan untuk masyarakat umum. Akhirnya terjadi ketidakkonsistenan dari para peserta yang mengikuti pelatihan tersebut. Berdasarkan informasi yang kami dapatkan, kami memiliki solusi untuk mengadakan pelatihan pembuatan kompos dari limbah rumah tangga organik dengan sasaran utama para kelompok tani di Desa Purasari.

pendek. Adapun metode-metode yang digunakan sebagai suatu solusi permasalahan yang ada adalah metode Studi Kasus sebagai langkah awal dalam pendekatan keilmuan yang akan diterapkan di masyarakat, metode Participatory Learning and Action yang diterapkan untuk program penyaluran air bersih sebagai program utama kelompok KKN 21 dan 22, dan metode Anaerob untuk penerapan program pelatihan pembuatan kompos yang telah dilaksanakan.

\section{Studi Kasus}

Studi kasus merupakan salah satu metode penelitian yang bertujuan untuk 
mempelajari tingkah laku dari peristiwa yang terjadi, perkembangan maupun keadaan yang sedang, dan telah terjadi di suatu lingkungan, yang melibatkan komunikasi baik secara individu, masyarakat baik secara sosial, kelompok maupun sebuah lembaga pemerintahan dan non pemerintahan.

Dalam penerapannya Studi Kasus membutuhkan kondisi yang dilakukan secara alami dan dialami langsung oleh peneliti agar dapat memperoleh data dan informasi yang sesuai tanpa unsur manipulatif data terutama di lingkugan masyarakat. Berikut merupakan tahapan yang dilakukan sebagai persiapan sebelum melaksanakan kegiatan.

a. Wawancara, adalah percakapan yang dilakukan antara dua orang atau lebih yang menghasilkan suatu informasi. Dengan memberikan pertanyaan dan mendapatkan jawaban dari sumber yang diwawancarai agar jawaban dapat dimanfaatkan untuk analisis masalah yang terjadi dari sudut pandang sumber yang diwawancarai.

b. Metode observasi, adalah teknik pengumpulan data yang didapatkan dari pengamatan terhadap objek-objek alam yang ada.

c. Survei lapangan, merupakan metode yang digunakan untuk melihat langsung lokasi sasaran agar kegiatan sesuai dengan sumber daya yang ada.

d. Metode dokumentasi, proses pencarian data berdasarkan data yang berupa profil desa, catatan, legenda, notulen rapat, dan sebagainya.
2. Metode Participatory Learning and Action (PLA)

Metode pelaksanaan pemberdayaan masyarakat menggunakan

Participatory Learning and Action (PLA) merupakan metode pemberdayaan dengan melibatkan masyarakat yang terdiri dari proses belajar sambil bekerja (Ibnouf dkk, 2015) untuk peyaluran air kepada rumah-rumah warga sehingga warga dapat mempergunakan air bersih untuk kebutuhan sehari-hari. Tahapan kegiatan pengabdian yang dilakukan dengan metode $P L A$, sebagai berikut:

1) Analisis situasi, pada tahap ini kelompok KKN 21 dan 22 menguraikan potensi, nilai strategis, kondisi sosial, dan ekonomi, serta permasalahan Desa Purasari berdasarkan data dan informasi dari Kepala Desa, RT, RW, dan masyarakat. Diperlukan partisipasi Kepala Desa Purasari, RT, RW, dan masyarakat untuk dapat secara terbuka memberikan informasi guna penentuan root of problem yang dihadapi.

2) Rancang pembuatan alat pompa air tanpa listrik dan jalur aliran air menggunakan pipa dengan mengikuti kontur tanah, pada tahap ini kelompok KKN 21 dan 22 melakukan transfer knowledge Ilmu Pengetahuan dan Teknologi (IPTEK) perguruan tinggi kepada masyarakat untuk bersama-sama melakukan rancang bangun agar alat tersebut dapat disesuaikan dengan kebutuhan masyarakat untuk pengaliran air.

\section{Metode Anaerob}

Metode anaerob merupakan metode pengolahan air limbah tanpa injeksi udara ke dalam proses pengolahan yang 
memerlukan inokulan mikroorganisme (starter) untuk mempercepat proses pengomposan. Inokulan merupakan mikroorganisme yang dapat menguraikan bahan organik dengan cepat dan efektif. Berdasarkan analisis permasalahan yang terjadi metode ini dapat dipergunakan untuk mengedukasi masyarakat Desa Purasari yang mayoritas penduduknya adalah petani dan kondisi wilayah yang memiliki luas sawah 150,00 Ha. Maka diadakan program kegiatan pelatihan pembuatan pupuk kompos.

Selanjutnya kelompok yang menjadi sasaran kegiatan pembuatan pupuk kompos adalah kelompok tani dan ibu Pemberdayaan Kesejahteraan Keluarga (PKK) di Desa Purasari. Rata-rata pendidikan anggota kelompok sasaran adalah SMP. Pada umumnya ibu-ibu ini bekerja sebagai petani (60\%), sisanya mengurus rumah tangga, dan dagang. Metode pelaksanaan yang digunakan dalam program pelatihan pembuatan pupuk kompos adalah metode anaerob

\section{REALISASI PROGRAM}

Program kerja utama Kuliah Kerja Nyata (KKN) kelompok 21 dan 22 adalah penyediaan fasilitas berupa pengolahan air limbah dan penyediaan air bersih melalui perpipaan di RT 02 RW 01 Desa Purasari, Kecamatan Leuwiliang, Kabupaten Bogor.

\section{Program yang Dilaksanakan}

Program unggulan merupakan program utama yang diajukan oleh anggota KKN di bidang Ilmu Kesehatan berupa proses pengolahan limbah dan program penyaluran air bersih yang diajukan oleh mahasiswa fakultas teknik. Program unggulan ini juga didampingi dengan program lain sebagai program kegiatan non yang pelaksanaannya dilakukan dengan memanfaatkan alat dan bahan-bahan limbah rumah tangga organik ini dibagi menjadi beberapa tahapan. Tahapan pertama penyuluhan materi tentang pupuk kompos dan metode anaerob dengan memanfaatkan alat dan bahanbahan limbah rumah tangga organik, tahapan kedua adalah memberikan penjelasan atau pelatihan pembuatan kompos limbah rumah tangga organik menjadi kompos pupuk cair organik. Tahapan ketiga adalah melakukan praktek proses pembuatan pupuk kompos cair. Kegiatan dilaksanakan dalam sekali waktu, kegiatan praktek difokuskan di lahan pertanian warga Desa Purasari dan hasil praktek diterapkan langsung di setiap rumah anggota kelompok tani yang terlibat. Diharapkan setiap rumah di Desa Purasari akan mampu menghasilkan pupuk kompos cair secara berkelanjutan dan jumlah sampah organik juga akan semakin berkurang.

tema yang memiliki peran yang tidak kalah penting dari program unggulan.

\section{Bidang Teknik}

Program penyaluran air bersih merupakan program unggulan yang sudah terealisasikan, program penyaluran air bersih dilaksanakan dengan melibatkan ketua RT 02, ketua RW 01, beserta warga Desa Purasari.

Kegiatan penyaluran air bersih ini bertujuan untuk menyalurkan air bersih kepada warga Desa Purasari yang mengalami kekurangan sumber daya air. 
Program penyaluran air bersih pada tanggal 11 agustus dimulai dengan melakukan survei lokasi sumber mata air di lingkungan RT 02 dan RW 01 yang bertujuan untuk mengetahui kondisi sumber mata air yang akan dialirkan ke lingkungan warga, dilanjutkan dengan pengecekkan $\mathrm{pH}$ air menggunakan $\mathrm{pH}$ meter yang bertujuan untuk mengetahui tingkatan asam dan basa dari air yang akan dialirkan, selanjutnya menentukan titik koordinat untuk jalur perpipaan agar dapat sesuai dengan peta situasi dan topografi di Desa Purasari. Pembuatan layout jalur perpipaan serta bak penampungan agar pada saat pembuatan jalur dan bak penampungan dapat sesuai dengan gambaran yang dibuat berdasarkan perhitungan yang telah dilakukan. Persiapan alat dan bahan yang dibutuhkan untuk penyaluran air. Pemasangan pipa dari sumber air ke pemukiman warga yang pada pengerjaannya dilaksanakan secara bergotong royong oleh ketua RT, ketua RW, dan warga RT 02 RW 01. Pembuatan bak penampungan di sumber mata air yang bertujuan untuk menampung aliran air yang keluar dari titik sumber mata air.

\section{Bidang Agama Islam}

a. Berpartisipasi dengan Pengajian Warga

Pengajian yang dilaksanakan terbagi menjadi dua yang meliputi pengajian ibu-ibu dan bapakbapak.

1) Pengajian rutin bersama ibuibu berlangsung di dua tempat, pengajian ini dihadiri oleh anggota KKN 22 bersamaan dengan jamaah pengajian dari Masjid Nurul Yaqqin dan jamaah majelis Nurul Huda yang dilaksannakan pada hari minggu pagi di Masjid Nurul Yaqqin yang terletak di Kampung Sinar Jaya RT 02 RW 01, Desa Purasari, Kecamatan Leuwiliang. Dan pada hari Selasa yang dilaksanakan di Majelis Nurul Huda yang terletak di Babakan Empang RT 02 RW 01, Desa Purasari, Kecamatan Leuwiliang. Pengajian ibu-ibu ini juga dilaksanakan pada Pukul 07.30-10.00 WIB. Kegiatan ini dilakukan untuk menumbuhkan rasa antusiasme kepada ibu-ibu, serta menjalin silaturahmi antara anggota KKN dengan warga.

Kegiatan pengajian rutin bersama ibu-ibu dimulai dengan membaca sholawat, pembacaan hadiah, sambutansambutan, ceramah yang disampaikan oleh tokoh agama dan doa penutup.

2) Pengajian rutinan anggota KKN bersama bapak-bapak di Kampung Babakan Empang dan Sinar Jaya RT 02 RW 01. Dilaksankan pada Pukul 20.00 di Masjid Al Muhtadin Kampung Babakan Empang dan pada Pukul 18.00 di Masjid Nurul Yaqqin Kampung Sinar Jaya. Kegiatan ini dilakukan untuk menumbuhkan rasa antusiasme di kalangan pemuda agar termotivasi untuk hadir ke pengajian bapakbapak yang telah rutin dilaksanakan. 
b. Bimbel dan Pengajian Anak anak Bimbingan belajar di Desa Purasari RT 02 RW 01 dilaksanakan secara rutin pada hari Senin dan Rabu di setiap minggunya. Pada bimbingan belajar ini, terdaftar 32 anak-anak yang di dalamnya terdiri dari tingkatan Pendidikan Anak Usia Dini (PAUD) sampai dengan Sekolah Dasar kelas enam. Kegiatan belajar ini dilaksanakan karena sebagai bentuk kepedulian kami pada pendidikan anak anak dan menanamkan suatu kebiasaan untuk mempelajari kembali apa yang telah dipelajari diluar jam sekolah formal. Maka dari itu kegiatan dilaksanakan pada Pukul 14.00-15.00 WIB yang mana para mahasiswa mengisi kegiatan dengan memberi materi serta membantu pekerjaan rumah yang tidak mereka pahami di sekolah.

Sedangkan untuk pengajian anak anak, mahasiswa memberi materi meliputi hadist, kosa kata bahasa Arab, dan kosa kata bahasa Inggris. Kegiatan ini berlangsung secara rutin pada hari Selasa dan Jum'at pada tiap minggunya Pukul 14.0015.00 WIB.

Kegiatan ini dimulai dengan pembukaan pada pukul 14.00, mahasiswa memberikan motivasi berupa Ice Breaking dan kegiatan inti, lalu dilanjutkan dengan penguatan berupa Tanya jawab, game, dan penutup.

c. Santunan Anak Yatim dan Dhuafa Kegiatan santunan anak yatim ini dilakukan di Taman Pendidikan Agama (TPA) Islam Nurul Ilmi yang beralamat di Kampung Babakan Empang, Desa Purasari,
Kecamatan Leuwiliang, Kabupaten Bogor. Kegiatan ini dilaksanakan pada tanggal 1 September 2019 pukul 08.00 s/d Selesai dengan kerja sama antara panitia dan anggota KKN untuk membantu jalannya kegiatan tersebut. Tema santunan ini yaitu Mengadakan Santunan Anak Yatim dan Dhuafa. Kegiatan ini dilaksanakan sebagai bentuk kepedulian kami anggota KKN dan TPA Islam Nurul Ilmi kepada anak anak Yatim dan Dhuafa di daerah Desa Purasari.

Kegiatan dimulai dengan pembacaan Sholawat, penyampaian sambutan, penampilan dari anak anak TPA Islam Nurul Ilmi, memberikan santunan kepada perwakilan anak yatim sebanyak lima belas orang dilanjutkan dengan penampilan penampilan hafalan doa doa pendek, ceramah serta diakhiri dengan acara penutup. Antusias dari warga sekitar sangat baik, terbukti dengan terlihatnya warga yang banyak membantu agar kegiatan ini terlaksana dengan baik dan meriah serta banyak juga tokoh masyarakat dan warga yang hadir.

\section{Bidang Kesehatan}

a. Senam dan Cek Kesehatan

Kegiatan cek kesehatan dan senam sehat dilaksanakan Karena pentingnya kesehatan, kegiatan ini bertujuan untuk mencegah terjadinya sakit dan juga mendeteksi sedini mungkin penyakit yang diderita sehingga dapat ditangani sesegera mungkin. Kegiatan dilaksanakan pada tanggal 31 Agustus 2019 Pukul 07.00-12.00 WIB bertempat di 
salah satu rumah warga RT 02/01, yakni Bapak Abdul Aziz. Warga yang ikut berpartisipasi dalam kegiatan senam dan cek kesehatan berjumlah seratus orang. Kegiatan diawali dengan senam kemudian dilanjut dengan cek kesehatan dasar yaitu cek tekanan darah, cek asam urat, cek kolesterol, cek gula darah, mengukur tinggi badan, mengukur berat badan, mengukur lingkar lengan, dan mengukur lingkar pinggang. Untuk pengecekkan darah dilakukan pengukuran dengan GCU, setiap orang diberi pilihan untuk memilih satu untuk di cek. Berdasarkan hasil tes Kesehatan terdapat 67 orang memiliki asam urat, gula darah 21 orang dan kolesterol 9 orang.

b. Penanaman Tanaman Obat

Salah satu program yang telah dilaksanakan yaitu program penanaman dan memberi pengetahuan mengenai khasiat tanaman herbal, kegiatan ini melibatkan warga dan anggota KKN sebagai pelaksana program. Penanaman Tanaman Obat dilaksanakan pada tanggal 24 Agustus 2019 bertempat di aula desa. Kegiatan ini dilaksanakan untuk memberikan edukasi kepada warga mengenai tanaman obat, karena warga kurang mengetahui tanaman obat yang dapat ditanami di pekarangan rumah. Sosialisasi Penanaman Tanaman Obat dilakukan setelah sosialisasi pembuatan kompos sudah selesai. Peserta yang hadir sekitar kurang lebih lima belas orang, kegiatan dimulai dengan pemberian pengetahuan mengenai tanaman obat yang telah kami siapkan, tanaman yang kami bawa diperlihatkan langsung kepada masyarakat agar masyarakat dapat mengetahui bentuk tanaman yang sedang diberitahukan apa saja manfaat yang terkandung di dalamnya. Setelah kegiatan selesai peserta yang hadir diberikan satu buah tanaman untuk di tanam di pekarangan rumah nya masing masing, dan tanaman lainnya diberikan kepada perwakilan ibu ibu PKK, dan dilakukan penanaman bersama satu buah pohon di rumah ibu ibu PKK. Masyarakat merasa senang dengan diberi bibit tanaman obat yang di mana tanaman ini masih belum ada di lingkungannya.

c. Pembuatan Kompos dari Limbah Organik

Pembuatan kompos dari limbah atau sampah rumah tangga dilaksanakan sebagai salah satu upaya kami dalam mengatasi masalah limbah rumah tangga yang terjadi di lingkungan masyarakat dan juga sebagai pelatihan agar warga dapat menekan biaya produksi pupuk kimia yang dapat mencemari lingkungan. Kegiatan ini melibatkan warga sebagai penerima pelatihan yang mengutamakan peserta berlatar pekerjaan sebagai petani dan kelompok tani di lingkungan Desa Purasari. Pembuatan Kompos dilaksanakan pada tanggal 24 Agustus 2019 bertempat di aula desa kegiatan ini berisi penjelasan manfaat dan bahan yang terkandung di kompos dilakukan 
oleh Ibu Eny selaku dosen Fakultas

Ilmu Kesehatan masyarakat.

Kemudian, demo pembuatan

kompos organik dan penjelasan mengenai manfaat dari kompos organik dilakukan oleh anggota

KKN 21 dan 22. Antusiasme petani dan ibu rumah tangga dengan adanya demo pembuatan kompos organik sangat terasa.

\section{Bidang Pendidikan}

Pelaksanaan Bimbingan Belajar (BIMBEL) Bimbingan belajar di Desa Purasari RT 02 RW 01 dilaksanakan secara rutin pada hari Senin dan Rabu di setiap minggunya. Pada bimbingan belajar ini, terdaftar 32 anak yang di dalamnya terdiri dari tingkatan Pendidikan Anak Usia Dini (PAUD) sampai dengan Sekolah Dasar mulai dari kelas satu hingga kelas enam. Kegiatan belajar ini dilaksanakan pada Pukul 14.00-15.00 WIB yang mana para mahasiswa mengisi kegiatan bimbingan belajar dengan memberi materi yang tidak mereka pahami di sekolah serta membantu pekerjaan rumah (PR) mereka. Dan juga mahasiswa memberi materi kosa kata bahasa Inggris. Kegiatan ini dilaksanakan karena melihat pentingnya pendidikan yang diajarkan diluar kelas, sebagai bentuk pengenalan kepada anak bahwa belajar dapat dilakukan dengan cara yang menyenangkan namun tetap efektif untuk dilakukan.

Progam bimbingan belajar diawali dengan pembukaan dan dilanjutkan dengan penyampaian materi oleh mahasiswa yang berpedoman pada observasi yang dilakukan melalui wawancara terhadap anak-anak yang telah mengikuti kegiatan. Kegiatan selanjutnya adalah penutup

\section{Bidang Ekonomi}

Program Cilik Gemar Menabung (Cilikbung)

Kegiatan ini merupakan salah satu cara untuk menanamkan rasa gemar menabung pada anak usia dini. Bercermin pada kata-kata bijak 'rajin pangkal pandai, hemat pangkal kaya'. Ungkapan kata-kata bijak ini seharusnya mulai kita tanamkan kepada anak-anak sejak usia dini. Maka telah dilaksanakan program kegiatan Cilikbung yang dilaksanakan dua kali selama pelaksanaan KKN yaitu pada tanggal 21 Agustus 2019 dan tanggal 28 Agustus 2019.

Karena menabung merupakan kegiatan yang dapat melatih kemampuan anak untuk memanajemen keuangannya sedari kecil, agar dapat dimanfaatkan kelak ketika anak anak sedang sangat membutuhkan. Peserta yang mengikuti kegiatan merupakan anak anak sekolah dasar di Desa Purasari yang mengikuti program kegiatan Bimbel. Mereka diajarkan apa itu menabung dan langsung diberikan celengan sebagai hadiah agar mereka dapat mempraktekkan langsung di rumahnya masing-masing dan setelah itu diadakan pertemuan kembali pada tanggal 28 Agustus untuk menghias celengan yang telah diisi oleh masing masing anak dan memberikan Reward kepada anak anak dengan kategori celengan terbagus hiasannya dan celengan terberat agar anak semakin bersemangat untuk menabung. Mereka terlihat antusias dan memberikan respon positif terhadap pentingnya menabung usia dini. Sehingga anakanak Desa Purasari telah mengerti 
tentang pentingnya menabung sejak dini dengan cara lebih berhemat dan dapat membelanjakan uang saku yang didapat dari orang tua dengan bijak.

\section{Bidang Hukum}

Sosialisasi Dampak Kenakalan

Remaja

Program kegiatan yang berlangsung pada hari Kamis tanggal 29 Agustus 2019 yang diadakan di SMP-SMA Muhammadiyah Puraseda dihadiri oleh seluruh anggota KKN 21-22 berjalan lancar. Kegiatan ini dilakukan karena kurangnya perhatian dari masyarakat sendiri mengenai

\section{KESIMPULAN}

Program kerja yang dilaksanakan oleh kelompok KKN 21 dan 22 terdiri dari program unggulan dan program non tema, berdasarkan kegiatan yang telah terlaksana dan pengalaman langsung anggota $\mathrm{KKN}$ Kelompok 21 dan 22 di Desa Purasari dapat disimpulkan bahwa:

1. Bidang Teknik

Kegiatan penyaluran air berjalan baik dan terlaksana berkat kerja sama dan kekompakan antara anggota KKN, Bapak Taufik ketua RT 02, Bapak Sarmat ketua RW 01, dan warga Desa Purasari.

2. Bidang Agama Islam

a. Berpartisipasi dengan Pengajian

Warga

Kegiatan ini telah terlaksana, mendapat sambutan baik dari warga dan menjadi penguat silaturahmi antara warga dan mahasiswa yang sedang menjalankan kegiatan KKN.

b. Bimbel dan Pengajian Anak anak Anak anak mendapatkan wawasan mengenai

pembelajaran kenakalan pada remaja beserta dampak yang akan ditimbulkan jika kenakalan itu terjadi. Acara meliputi pembukaan dengan doa kemudian sambutan, setelah itu materi dari tiga perspektif hukum, kesehatan, dan agama islam. Di pertengahan terdapat acara hiburan musik dan pembagian doorprize. Di penghujung acara kemudian ditutup dengan doa dan foto bersama peserta. Kegiatan dihadiri oleh seratus peserta yang terdiri dari lima puluh laki-laki dan lima puluh perempuan dan turut serta ibu dan bapak guru yang ikut untuk mengawasi berjalannya acara.

keagamaan, memahami kosa kata bahasa Arab dan dapat menghafal hadist. Anak-anak juga dapat mengetahui bahwa pembelajaran agama itu sangat penting bagi kehidupan mereka.

c. Santunan Anak Yatim dan Dhuafa Kegiatan santunan anak yatim dan dhuafa yang diselenggarakan oleh TPA Islam Nurul Ilmi yang diketuai oleh Ibu Didah bekerja sama dengan Mahasiswa KKN 2122 dalam pelaksanaan penyaluran dana melalui donatur. Serta Donasi sudah tersalurkan kepada anak yatim dan dhuafa sebanyak lima belas orang.

3. Bidang Kesehatan

a. Senam dan Cek Kesehatan

Warga mengetahui hasil tensi darah, cek kolesterol, asam urat, dan gula darah masing-masing setelah diadakannya pengecekan kesehatan. Warga mengetahui hasil cek kesehatan dasar seperti tinggi badan, berat badan, lingkar pinggang, dan 
lingkar lengan setelah diadakannya pengecekkan.

b. Penanaman Tanaman Obat

Warga mengetahui manfaatmanfaat tanaman obat yang diberikan kepada warga dan menanami tanaman obat di pekarangan rumah.

c. Pembuatan Kompos dari Limbah Organik

Warga mengetahui cara pembuatan kompos untuk tanaman dan dapat mempraktekannya untuk kebutuhan pertanian.

4. Bidang Pendidikan

Anak-anak usia dini/PAUD dapat memahami sedikit huruf, angka dan dapat mengejanya. Anak-anak Sekolah Dasar dapat menulis, membaca, berhitung. Dan kegiatan pembelajaran ini dapat memotivasi anak anak dengan penjelasan yang telah diberikan agar dapat menambah wawasan dan ilmu pengetahuannya. Anak anak dapat mengetahui juga tentang kosakata Bahasa inggris.

5. Bidang Ekonomi

Anak-anak sudah termotivasi untuk menabung karena mengetahui pentingnya manfaat menabung.

6. Bidang Hukum

Anak-anak SMA di sekolah SMP dan SMA Muhammadiyah sudah mengetahui tentang dampak kenakalan remaja yang dilihat berdasarkan kacamata hukum, kesehatan, dan agama islam. 


\section{DAFTAR PUSTAKA}

Dalimunthe, M. B. Dkk. (2019). Penerapan Ipteks untuk Pengembangan Potensi Limbah Tempurung sebagai Upaya Peningkatan Pendapatan Masyarakat. Universitas Pembangunan Pancabudi.Vol. 4, No. 2.

Data Profil Desa dan Kelurahan. (2018). Daftar Isian Potensi Desa dan Kelurahan.

Dwimawati, E., Beliansyah, F., dan Zulfa, S. A. (2019). Pemberdayaan Masyarakat melalui Pemanfaatan Teknologi dalam Rangka Meningkatkan Kualitas Sumber Daya Manusia di Desa Gunung Menyan. Vol. 3, No. 1.

Fathimah, A., Agnesia, U., dan Abdul, R. (2019). Pemberdayaan Masyarakat melalui Peningkatan Mutu Pendidikan, Ekonomi dan Kesehatan Studi Kasus Desa Cibeber II. Vol. 3, No. 1.

Hariati, F. \& Lutfi, M. (2018). Penelitian Teknis Sistem Penyediaan Air Bersih Berbasis Masyarakat (Studi Kasus Kampung Siliwangi, Cigombong, Kabupaten Bogor). Publikasi di Jurnal “KOMPOSIT”. ISSN: 26153513, Vol. 2, No. 1.

Lutfi, M., Gustian, H., dan Zen, M. (2017). Implementasi "SIDes" (Sistem Informasi Desa) dalam Rangka Pengelolaan dan Updating Database Desa Cibeuteung Udik Kecamatan
Ciseeng, Kabupaten Bogor. Bogor: Universitas Ibn Khaldun.

Muhsinin, S. Dkk. (2019). Peningkatan Potensi Ibu Rumah Tangga dalam Mengolah Sampah Organik Rumah Tangga Menggunakan Metode Takakura di Desa Cibiru Wetan, Kabupaten Bandung.Vol. 4, No. 2.

Pramono, G. E., Aminah. S., dan Rika. (2019). Pembangunan Sistem Pengairan dalam Upaya Memenuhi Kebutuhan Masyarakat Dusun Cengal.Vol. 3, No. 1.

Profil Desa Purasari. (2018). Profil Desa Purasari.

Rohmah, L. \& Krisdiyanto, D. (2016). Pengadaan Cek Kesehatan Gratis (Lansia) untuk Menciptakan Masyarakat yang Sadar dan Peduli Terhadap Kesehatan di Jail, Gayamhargo, Prambanan, Sleman.Vol. 16, No. 1.

Setianingsih, A. Dkk. (2015). Laporan Kelompok Kuliah Kerja Nyata $(K K N)$ Universitas Negeri Yogyakarta.

Sobari, A., Hermawansyah., dan Jubaidi. (2017). Memanfaatkan Potensi Lingkungan, melalui Pemberdayaan Air (Bak Penampung Air) Agar Efektif dan Efisien di Kampung Sinarwangi Desa Tapos 1 Kecamatan Tenjolaya.Vol. 1, No. 1. 